\title{
Spirituality in Pedagogy A Qualitative Study of Teachers Values in High School
}

\author{
Erba Rozalina \\ \{erba.rozalina@uinjkt.ac.id\} \\ UIN Syarif Hidayatullah Jakarta, Indonesia
}

\begin{abstract}
This study aim to develop the spirituality to be used in education by exploring many concept in its, such as: education meaning, the educators examining of their own spiritual perspective and practices, and education illustrating the value of spirituality as both an analytic tool and a course topic. Spiritual in pedagogy is a practice of education that is based on the sublime and transcendental values, both those originating from religion and culture, that guide, support, and motivate a teacher in doing his or her profession; values that are inherent in the teacher's behaviors as an authentic way of living his or her life. Understanding the origin of this spirituality is very important in the developing millennial generation. So that teachers should be continuously guided in order to adjust their knowledge and skills to the need of the contemporary world. This study was conducted in SMK Perbankan Syariah Al-Izhar School Pekanbaru, which is established under Daar En Niswah Foundation. The achievements are the part of best school life years. Those achievements may include personal academic and sports or an extracurricular achievements. The findings of this study are that the spiritual values include religiosity, sincerity, discipline, affection, responsibility, patience, hard work and consistency.
\end{abstract}

Key Words : Spirituality, Pedagogy, Achievements

\section{INTRODUCTION}

Education is one of the key vehicles for the intellectual dan professional development of our people and plays an increasingly role in supporting a stronger and more globally competitive Indonesia. The future of Indonesia is the quality of education today. The moral crisis that is now endemic in the midst of the nation, especially our young generation is not because of the poor education system that we apply today, but rather because what we have done has lost its essence. 
The flow of diverse physical and non-physical resources (data, informations and knowledge) from one place to another freely and openly) is phenomenas that occur in the $21^{\text {st }}$ century. The winner is a country that has a quality human resources and superior characters, the best and cheapest quality of goods and services as well as a conductive work, free of extortion and legal certainty.

Indonesia peoples that holds a philosophy of life based on religion, believe that progress is not merely measured by material progress, but essential progress is when nation can harmonize all its life activities with religions guidance. There for the happiness can be felt dan the blessing of life can be achieved, as an according to the Law of National Education System No 20 of 2003. In one a moment time Nelson Mandela analogied the education as a powerfull weapon. Everyone can use this weapon to change the world. Education is used to be moral, social, and economic well being of the societies, cultivates knowledge, understanding and values among citizens, and enhances human capascity to create a generation future.

Answering these challenges, it's time to develop and use spiritual-based education, where Daniel Goleman's research shows that the importance to emotional intelligence for one's success should make scientist and education practitioners continue to develop spirituality-based education whose aim to provide religious education [1].

Raising awareness of the fact that humans being are hightly complex creaturs and individual multisystems is driving the emergence of various scientific studies arounds spirituality. According to Jung that humans being is not only psychosexual and psychosocial creatures, but also psychospiritual beings [2]. Spirituality is a concept that have many prespectives. It can be interpreted as transcendental which is the highest achievement in individual development, as a motivation that encourages individual to seek meaning and purpose in life. In general, Spirituality includes a sense of connection to something bigger than humankinds and meaning in life. Maslow on spiritual life said that spiritual life constitutes the most essential humanity and this value made distinguishes humans being from other creatures.[3].

The above statement point that spirituality is a part of individual development. Spiritual can encourage humans to look for the nature of their existences. Finally, can guide the individual in achieving self-actualization as the creation of Allah. Any individual are able to appreciate the beauty of life, honesty, unity, and sacrifice in life. Futhermore, individuals can appreciate their other living creatures.

Not easy to provide the term of spiritual, but the reserchers believe its more important, there fore they offered a description instead. Howard Gardner who has known as a founder of the multiple intelligence sistems, formed the spiritual studies as a framework of his teori. Emotional Quotient (EQ) and Spiritual Quotient (SQ) are the most recently suggested by him. As well as Gardner, Daniel Goldman in 1995 has suggested that Emotional Quotient (EQ) give mankinds an awareness of their feeling. It provides human with many values like: empathy, compassion, motivation and the ability to respond appropriated to pan or pleasures. At the last of his statement, Goleman has pointed out that Emotional Quotient (EQ) is a basic requirement for the effectives use of Intellectual Quotient (IQ). In other view, Danah Zohar and her husband, Marshall have applied the concept of Spiritual Quotient (SQ) to the discussion conserning IQ and EQ. According them, SQ helps people to assess the most meaningful course of action. With Spiritual Quotient (SQ) address and solve problems of meaning and value of people. The autors claim that SQ is the 
necessary foundation for the effective functioning of both IQ and EQ. SQ is human's ultimate intelligences [4].

Danah Zohar and her husband Marshall, have equated spirituality with super intelligence. According both of them, spirituality may be defined as contextualizing, meaning giving and transformative intelligence. Spiritual Intelligence helps humankinds to assess the most meaningful course of action. With Spiritual Quotient (SQ), human being address and solce their problems, meaning and value.

As well as scientist above, the idea of spiritual intelligence has also been studied by Robert A. Emmons [5]. Emmons describes spiritual intelligence as the adaptive use of spiritual information to facilitate everyday problem solving and goal attainment.

Khalil Khavari in his book said that the spiritual intelligence is the faculty of non material dimension of the human soul. Everyone has this dimension. They can recognize its well, as well as they know their body. This intelligence is an endless diamond that everyone has. rub it to its glitter with great determination and use it to achieve lasting happiness. Like other forms of intelligence (intellectual and emotional intelligence), spiritual intelligence can be enhanced and reduced.[6].

Based on some of the above understanding can be concluded that the definition of spiritual intelligence is the potential ability of every human being that makes him able to realize and determine the meaning, values, morals, and love of the greater power and fellow living beings, because they feel as part of the whole. So as to make humans able to put themselves and live more positively with wisdom, peace, and ultimate happiness.

Spiritual intelligence is human intelligence that must be sharpened with both being used to relate to God and to place meaning in a broader context so that they can interact among fellow humans with good interaction.

In the third millennium, also known as the new age, ethical values and spirituality play an important role in various aspects of human life. Speeding of change and global competition has leads to uncertain life patterns. On the other hand, ethical values and spirituality will plays an important role not only in the field social and religious, but also in the world education as a noble industry (noble industry). An education is the most responsible institution for the quality of human resources and the quality of civilization in the future. Therefore an education requires teachers who have spiritual insight in fostering and developing education.

The idea of the value of spirituality in the educational dimension, is a concept that is being developed by educational reformers [7]. It is recognized that this concept is an ijtihad in order to realize the vision of spirituality in all aspects of the education process. In this context, education is a truly and noble struggle to build souls, and personalities so that human beings are created ahsani taqwim (humanization), and instead liberate (liberalization) from the fetters that prevent the emancipation from various forms of immorality, poverty and ignorance.

An education has not been integrated in understanding humans. Education so far is more properly called teaching which has a goal to make children have knowledge but does not make them smart. Therefore, education must look at humans as a whole and integrated. It must be interpreted that education must look the humans as a whole and integrated in order to liberate humans.

Educational researchers in the western country have an interest in spiritual pedagogy. This theory applies many values that derived from religion and culture in the practice of school's 
education. These values most important to the teacher to guide their behavior. The teachers teach not only to carry out their duty but in order to get something meaningful and useful.

Shimabukuro (2008), quoting the ideas of Cambron_McCabe and Dutton, asserted that the approaches in teaching and instruction have experienced changes and development that narrow into three (3) types of approaches; 1). Transmissional Approach, 2). Generative Approach and, 3). Transformative Approach.[8].

The transmissional approach positions learners in the passive position, as a receiver of materials, and object of instruction. Teachers have the position of material deliverer, while students merely accept the subject that the teachers gave as necessary to for them. This approach we can find in many school in Indonesia.

The generative approach encouraged the studenst to create knowledge constructed on the basis of their own knowledge through interaction with learing the materials, teachers, and facilitators. Studengts knowledge is created layer by layer.

And the last approach, transformative approach. Through this approach the students can to penetrate into a deeper layer of instruction, which provides meaning t think critically about the world. Thus, learning is simultaneously an individual and transformative process. This approach is based on sosial activities. Through this approach students afre encouraged to use their knowledge in social transformation.

Today, in industry periode, we need a new approach, pedagogic practices based on spiritual values. Through this approach, the teachers implement the education and instruction on the spiritual value that also become the foundation of their profession such as lovely, patience, humility, empaty, sensibility, holistic, tolerance and many values else. Understanding the origin of this spiritual values is very importand in developing the millennial generation, so that the teachers should be continuously guided in order to adjust their knowledge and skill to the needs of the contemporary world. Teachers should be aware that today, students are the native speakers of the computers language, video games and internet. There for, the teachers have to be able to do the spiritual values in their teaching in the school.

Awareness of the importance of pedagogy of spiritual-oriented teaching, has become a common concern . According to Shimabukuro (2008) there are five (5) characteristics of teachers in spiritual pedagogys; 1). Teachers understand students spiritual development and experience. 2). Teachers take the contemplative attitude. They closed to their students, and always think of their students future, knowledge, and the way dto guide them. 3). Teachers show magnanimity. This is shown by being open to the presence and dynamics of the holy spirit within themselves, and the school community. Magnanimity here has a broad meaning, which among others include being magnanimous towards different views among teachers, children displeasing behaviors, and less conduct school environment. 4). Teachers have interpersonal sensibility in performaing their profession, namely during interacting with the students, other teachers, school principal, and students' parents. 5). Teachers do various activities with the main motivation to teach. If teachers look weak and unmotivated, students will be negatives impacted; their motivation to learn will decline. In this case, teachers should take advantage of instruction.

Teachers who active the spiritual values within students through certain instructional models should have spiritual leadership. Spiritual leadership should be guided and developed through routine spiritual practices, so that eventually they will embody into the characters of a teachers. 
Based on the above explanations, a question arises concerning what values are made the foundation by teachers in performing their profession.

\section{METHODS}

This research was approached with a qualitative. The qualitative used in this research is to know and describe clearly and in detail the thoughts, feelings, and ideas of spiritual-oriented teaching at the SMK Al-Izhar School Pekanbaru. Data were collected through an observations on 10 teachers activities, in-depth interviews them with the researcher that plays the role of research instrument and documentations. The data sources in this study are teachers as key informants. Data sources from documents are chosen based on their relevance with research purposes. When will visit location and informant, local time and conditions be considered by researchers. The data that has been collected is then verified by the criteria recommended by Lincoln \& Guba (1985), namely (1)credibility with continuous observation, peer discussion and member check, (2) transferability by providing a description detailed research findings, (3) dependability by asking several people the auditor to audit it, and (4) confirmability, namely research results of research by expert

\section{RESULTS}

Based on data analysis, the results obtained research formulated in the form of propositions as follows.

1. The Values of The Foundation for Profesional Practice

The finding show that the spiritual values has applied by teachers SMK AL-Izhar School to make the foundation in their performing are:

a. Lovely: teaching with love makes class fun, always smiling, say salam when they meet each others, giving appreciation to students whatever the results, playing together with students during a break.

b. Responsibility: responsible to guidance the students physically and spirituality, understanding the students as an individual or as a group, providing various information that needed in the learning process, promoting thes students access and success

c. Sense of Sincerely: doing a work always with heart that clean from purpose (expecting a reward) and pure from the bottom of the heart not because of coercion from others and with a healty heart (a healty soul), doing something solely because of God.

d. Innovativeness and Creativities: tobe able to create something unique and different for himself and his students progress, tobe able to use technology well, such as computers, laptops, and internet, creating new ideas, looks different, not rigid but still has principles, likes to make an experiments or trials in learning methods. 
e. Disciplines: discipline in performing tasks, comes earlier, performing all his tasks in orderly manner

2. The Source of Value:

a. Religion: For respondents the most common source of guidance is religion beliefe to reach the benefits in the world and the hereafter. If someone does something based on religion, the act will produce good results and beneficial and positive impact for himself and his environment.

b. Family: For respondents, their family is the main vehicle for the inheritance of the their civilization and culture, because within the family the basic values of human relations are formed and practiced.

c. Frends: Friends can change the teacher's value system and learn to understand more meaning into their lives

d. Books: Books are a source of various information that can open teacher horizons about various things such as science, economics, social, culture, politics, and other aspects of life. In addition, by reading, can help change the future, and can increase the intelligence of teacher minds

\section{CONCLUSION}

Spiritual pedagogy is a field of study which explains the source of values through the religions, families, friends, and books. The spiritual values include lovely, responsibility, sense of sincerely, innovativeness, creativities and disciplines. Finally, these values encourage them, and become the foundation for the teacher inside carrying out his profession as an educator, teacher,or parents. The dominant values for the teachers in carrying out their profession is religion which is the main source and the most complete guide for humans life in various fields. Thus, education is held based on religious values can be categorized as pedagogical spiritual, if the religious value is really coloring the educational process operationally, actual, and consistent.

\section{REFERENCES}

[1]. Daniel Goleman, Emotional Intelligent: Why It Can Matter More Than IQ (New York: Random House Publishing Group 2012)

[2]. Carl Gustav Jung, Modern Man In Search of A Soul, (New York: London \& New York, 2001)

[3]. Frank G. Goble, Mashab Ketiga Psikologi Humanistik Abraham Maslow, (Yogyakarta: Kanisius, 1987)

[4]. Danah Zohar \& Ian Marshall, SQ; Memanfaatkan Kecerdasan Spiritual dalam Berfikir Integralistik dan Holistik untuk Memaknai Kehidupan, ( Bandung: Mizan, 2008)

[5]. Roberts A. Emmons, The Psychology of Ultimate Concerns; Multiple Inttelligence, (McGraww Hill: International Edition, McGraw Hill, 2002) 
[6]. Khalil Khavari, A, Spiritual Intelligence; (A Practical Guide to Personal Happiness), (Canada: White Mountain Publications, 2000).

[7]. G. Shimabukuro, Toward a Pedagogy Grounded in Christian Spirituality. Catolic Education: A Journal of Inquiry and Practice, Vol. 11 (4).2008

[8]. Arifin. I (Editor), Penelitian Kualitatif dalam Ilmu-Ilmu Sosial dan Keagamaan, (Malang: Kalimasahada Press, 1996).

[9]. Bertens,Kees, Psikoanalisa Sigmund Freud (Jakarta: Gramedia Pustaka Utama, 2006)

[10]. Ristan. K, Upaya Pengembangan Profesionalisme Guru Sekolah Dasar, Jurnal Ilmu Pendidikan, No,3 Tahun 2005.

[11]. Saleh, Bekerja dengan Hati Nurani, ( Jakarta: Erlangga, 2005). 